\title{
THE RELATIONSHIP BETWEEN IDEOLOGY AND VOTING PREFERENCES IN THE TIME PERSPECTIVE: AN INDICATOR OF THE IDEOLOGICAL MATURATION OF A YOUNG DEMOCRACY?
}

\author{
Goran Milas \\ Institute for Social Sciences Ivo Pilar \\ Marulićev trg 19, 10000 Zagreb, Croatia \\ goran.milas@pilar.hr \\ Boris Mlačić \\ Institute for Social Sciences Ivo Pilar \\ Marulićev trg 19, 10000 Zagreb, Croatia \\ boris.mlacic@pilar.hr
}

\begin{abstract}
Much research has been conducted on the relationship between ideology, voter preferences and electoral choice. However, due to the complexity of the relationship, differences in the understanding of ideology and the diversity of political systems, the issue has not yet been fully explored. Current research approaches the problems by monitoring the dynamics of change in the association between ideological position and party preferences over time in Croatia. Data for the study were collected in three surveys conducted in $2003(\mathrm{~N}=1248), 2014(\mathrm{~N}=1000)$ and $2016(\mathrm{~N}=750)$ on nationally representative samples of the Croatian adult population. The ideological position of an individual was measured in two ways, using General Social Attitude Scale (SAS_G) and left-right dimension self-placement. Political party preferences were measured by the reported electoral choice in the previous elections and the expressed voting choice in the forthcoming elections. The results of the current study indicate a steady increase in the correlation between ideological factors and political preferences over the years. In the paper we argue that the observed increase in the correspondence between one's own ideology and the preference for a political party could be an additional indicator of democratic consolidation in transitional and post-transitional countries like Croatia. However, unlike the democratic consolidation taking place on the outside and involving the construction of democratic institutions, this is a change in the minds of citizens who broaden and deepen their political culture, knowledge of ideology, political competence and are becoming more aware of implications of their own electoral decisions.
\end{abstract}

Key words: ideology, social attitudes, political attitudes, political preferences, electoral choice, Croatia 


\section{INTRODUCTION}

Numerous studies have shown that the ideology espoused by an individual is an important determinant of his or her political preferences and electoral choice (Elff, 2017). Although such a finding seems obvious, throughout history, across countries and various political systems, a number of factors have hindered the possibility of drawing a clear conclusion about the relationship between ideology and electoral behavior. We will first briefly mention the most substantial obstacles that stand in the way of attributing one's electoral choice to the advocated ideology. Then we will argue why we believe that the increase in the magnitude of the relationship between ideology and voting preferences could be used as a valuable indicator of the maturation of a young democracy. In this way, instead of considering the relationship between ideology and political preferences as a means to better predict the results of elections, we will try to see if it can be used as an indicator of the maturation of the electorate and democracy as a whole. But in order to get a true picture of the relationship between these constructs, we must first consider the factors that can distort it. There are at least four reasons why the association between ideology and electoral preferences is difficult to determine.

First, it is questionable as to what extent voters are informed and understand a particular ideology. Some of the groundbreaking studies of electoral behavior have cast doubt on the rationality of voters (Campbell et al., 1960; Converse, 1964) indicating that they do not possess a coherent ideological position but adjust their own attitudes in accordance with previously formed identification with the party.

Second, the notion of ideology has been a subject of controversy among experts. The most radical ones after the Second World War spoke of the "end of ideology" primarily because of a lack of logical consistency in voters' minds (Converse, 1964), but also for a number of other reasons, including the then prevailing tendency among psychologists to reject dispositional and embrace situational explanations (Jost, 2006). Yet, even among authors who agree on its importance, ideology is defined very differently. In the philosophical and sociological tradition, ideology has in the past been often defined as a distorted image of the world (Habermas, 1989) constructed to conceal the exploitative nature of society (Marx \& Engels, 1974), or a kind of twisted image in the service of the defense of the social system (Knight, 2006). Among psychologists, though, it is much more common to define ideology as a value-neutral configuration of ideas and attitudes linked in a recognizable and coherent pattern (Eysenck, 1944; Converse, 2000). Ideology can, however, also be viewed as a set of ideas that determine the political goals and political position of a political party (Elff, 2017).

Third, whereas some authors identify ideology through the well-established left-right dimension, others derive it empirically utilizing the bottom-up approach. Among many empirically founded models of ideology, we find both unidimensional as well as multidimensional ones. In the realm of political sciences, ideology 
is often identified with the left-right dimension, the term coined during the French Revolution (1789) referring to the seating arrangement of the French Assembly, in which regime supporters sat on the right and opponents on the left (Knapp \& Wright, 2006). An approach based on the traditional left-right continuum concept is advocated by Jost and colleagues (Jost, Federico \& Napier, 2009; Jost, Glaser, Kruglanski \& Sulloway, 2003).

However, the widely accepted left-right model of ideology has never been shown to be sufficient in explaining the whole range of political and social attitudes. In contrast to this largely theoretical approach, psychologists have been aiming to define the content of ideology empirically.

The first such attempt was the approach taken by members of the Frankfurt School (Adorno, Frenkel-Brunswick, Levinson \& Sanford, 1950), who advocated the idea that social and ideological attitudes are structured around a single dimension rooted in a personality trait called authoritarianism. Despite its popularity and simplicity, one-dimensional models of social and sociological attitudes have never been supported by empirical findings. Series of studies that emerged shortly after the influential study by Adorno et al. (1950), showed that at least two, and probably more dimensions are needed to explain the structure of social and ideological attitudes. In one of the pioneering studies in political psychology (1954), Eysenck established the existence of two dimensions: Radicalism vs. Conservatism and Toughmindedness vs. Tendermindedness. His study was followed by the research of Ferguson (1973), Wilson (1973) and Kerlinger (1972) whose models also rested on two ideological dimensions.

More recently, the two-dimensional model gained additional empirical support. Research combining two distinct measures of social attitudes, right-wing authoritarianism (RWA) (Altemeyer, 1981) and social dominance orientation (SDO) (Sidanius \& Pratto, 1999) showed these constructs are largely independent and correlate differently with other relevant variables (Duckitt \& Sibley, 2009). The issue of the structuring of ideology has recently been addressed utilizing a lexical approach (Saucier, 2000) which revealed a four-dimensional model including dimensions of traditional religiosity, materialism, liberalism and spirituality (Saucier, 2013).

Croatian researchers have approached the problem of ideology structure using a combination of content and factor analysis on the existing social attitudes scales (Milas, Mlačić \& Mikloušić, 2013). The starting point of the analysis was the content analysis of items gathered from several social attitudes scales and supplemented with items describing issues considered relevant to the individual's political and ideological position (detailed information on the procedure are provided in Milas et al, 2013). The content analysis was followed by a series of factor analyses and the structure of social attitudes was determined over several studies (Milas, 2004; Milas \& Rihtar, 1998; Milas \& Žakić Milas, 2003). A five-dimensional model was ultimately proposed consisting of Religiosity, Sexual freedom, Cosmopolitism, Modern technology and Social justice (Milas et al, 2013). 
Fourth, instead of ideology, some theories emphasize other factors, such as class (Jansen, Evans \& Graaf, 2013), religion (Evans \& De Graaf, 2013) or identification with the party (Campbell et. Al., 1954; Bowler, 2017) as the most important determinants of electoral choice. Indeed, many studies have shown that electoral choice is related to these variables. However, correlational research alone cannot clearly explain which of these variables are causal agents and which of them are just correlates.

The problem of determining the association between ideology and electoral choice is further complicated in countries that went through transition and have a relatively short-lived democratic tradition. In evaluating the role of ideology as a possible determinant of electoral decision, it can prove useful in distinguishing between long-established democracies and recent democracies or still democratizing regimes. For citizens of established democracies, not only the fundamentals of democratic functioning are well known and widely accepted (Mishler \& Rose, 2001) but also the fundamentals of ideology and the ability of voters to recognize political parties from different parts of the ideological specter. We assume that the relationship between ideology and electoral behavior can be considered as a kind of ideological maturation of the electorate that accompanies democratic consolidation, the term mainly used to describe the transition from autocratic regimes to democratic ones, but also the transition from liberal to advanced democracies (Schedler, 1998). By analogy, ideological maturation should, in the minds of voters, produce a consolidation of knowledge about ideology, politics and functioning of democracy making people aware of the implications of their choices and thus increasing the correlation between ideology and voting preferences.

We can thus speculate that the relationship between ideology and electoral choice in emerging and transitional democracies may be weaker than in well-established ones. We can further expect that with the passage of time in young democracies, the importance of ideological factors as predictors of party preference and electoral choice will gain in importance.

\section{Current study}

As previously discussed, to determine both the nature and the magnitude of the relationship between ideology and electoral choice is an extremely difficult task due to a variety of reasons, most notably a differently defined ideology and diversity of political systems in which this association can be studied. The current study approaches the problem from the perspective of young post-transitional democracy. Countries such as Croatia pose an additional challenge in studying the importance of ideology in electoral choice, but at the same time may offer an advantage when studied in a time perspective.

Voters in developing democracies may have insufficient knowledge of the ideology and mode of functioning of democracy, as well as a reduced ability to iden- 
tify political parties from the political spectrum. In addition, the parties may not have been able to clearly profile themselves politically as the democracy has been introduced only recently. This claim can be supported by the previous research conducted in Croatia which suggested that in the years following the introduction of democracy, ideology played a relatively limited role as a predictor of voting intentions and party preferences (Milas \& Rihtar 1997) and that voters were largely inconsistent. Not only did many of them intend to change the party they were going to vote for compared to their previous choice, but also intended to vote for an ideologically incongruent party (Milas, 2000).

We believe that the time perspective gained by linking several successive surveys over time (from 2003 to 2016) can facilitate monitoring the maturation of the electorate. Maturation is here viewed mainly as a growth in the importance of ideological reasons underlying voting decision, or more precisely, an increase in the association between ideological dimensions and electoral choice.

We further believe that the electoral decision will shift from momentary and accidental reasons to deeper, ideological ones, which will at the same time allow citizens to develop party identification. Such democratic maturation also implies that over time, voters will tend to guide themselves not only on the basis of the global and monolithic left-to-right dimension, but also based on the more specific ideological dimensions that embody basic social attitudes.

We therefore expect that maturation of a young and, in certain waves of this study, developing democracy could be indicated by a twofold phenomenon: (1) the increase of importance of ideological over accidental factors in reaching voting decision and party preferences and (2) the increase of more specific ideological factors over a general one.

Specifically, the objectives and associated research hypotheses are:

1. Identify the role of ideology as a predictor and a likely determinant of electoral choice and voting preferences among Croatian citizens. We assume that the proportion of variance of party preferences explained by ideological determinants will be limited. However, we expect an increase in importance of ideological factors over the course of time.

2. Compare the association between ideology and electoral choice/voting preferences at different points of time. We suppose that over time the correlation between ideology and party preferences will steadily increase, which we expect may be an indicator of the ongoing process of ideological and democratic maturation.

3 . Explore the predictive power of the global left-right self-placement dimension compared to the predictive power of general social attitudes. We expect that over time, general social attitudes will gain in importance, equally as predictors of electoral behavior and left-right dimensions. 


\section{METHOD}

\section{Participants}

Data for the study were collected in three national surveys conducted in 2003 (Lamza Posavec, Ferić \& Rihtar, 2003), 2014 (Miletić, 2014) and 2016 (Kaliterna Lipovčan, 2016). On all three occasions, probabilistic multistage, stratified samples of Croatian adult population were utilized. The selection of settlements and number of sample points within each settlement were proportional to their size. Households in each sample as well as respondents within households were consistently selected at random. The samples were nationally representative and thus comparable to each other. The sample from the 2003 survey included 1248 respondents; the one from 2014, 1000 respondents; and the one from 2016, 750 participants.

\section{Procedure}

Prior to the fieldwork, an approval for each survey was issued from the Ethics Committee at the Ivo Pilar Institute. To ensure honesty and reduce non-response rate, anonymity was guaranteed to respondents in several ways. Questionnaires were not signed, the names of respondents were not recorded and upon completion of the interview, respondents were able to mix their questionnaire with others, to prevent a subsequent identification of their responses.

Data collection was performed using a face to face surveying method in households with the assistance of expertly trained field associates. In addition to the measures and items presented in this paper, the questionnaire contained a whole range of other measures and instruments, so the interview with the respondent lasted on average 45-50 minutes.

\section{Measures}

Socioeconomic Status. To control for socioeconomic status as a possible determinant of electoral choice, two indicators have been used in all three surveys: Education and Monthly household income per household member.

General Social Attitudes. General Social Attitude Scale (SAS_G) is a multidimensional instrument based on the catch-phrase approach proposed by Wilson and Patterson (1968) consisting of five subscales labeled Religiosity, Sexual Freedom, Cosmopolitism, Modern technology and Social justice that has been validated in a large sample of Croatian university students (Milas et al, 2013). The Scale demonstrated acceptable psychometric properties and some previous research on criterion validity (Milas \& Burušić, 2004) showed that it is predictive of relevant attitudes and political behavior. Given the limited space in the questionnaire, different ver- 
sions of the scale were used at different time points: 2003 15-item version, 2014 10-item version, and 2016 full 25 -item version. However, despite their brevity, all scales showed very good psychometric characteristics and complete comparability. Even the shortest scale with only two items per dimension showed very good psychometric properties. Internal consistency measured by the Cronbach's alpha coefficient varied from .81 to .94 with median .91. Correlations between short twoitem subscales with full size five-item scales ranged from .84 to .96 with median value 91 .

Left-Right ideological position. We used the left-right self-placement 10-point scale as one of the most widely used measures for estimating ideological position of both voters and parties. It is believed that such a scale can accurately summarize the ideological positions of a voter. Previous research confirmed the usefulness of the scale, demonstrating that individuals can easily place themselves on the left-right continuum in a coherent manner (Laponce, 1970; Klingemann, 1972) however, with some limitations due to the differing notions of 'left' and 'right' among citizens (Bauer, Barberá, Ackrmann \& Venetz, 2017).

Voting preferences. To find out about their current voting preferences and intentions we asked our respondents an open ended question: If you went to the upcoming elections to the Croatian Parliament, who would you vote for?

Electoral choice. In addition to the current preferences we also asked about past voting behavior: Who did you vote for in the last parliamentary elections?

Both open-ended questions were later coded using an existing list of political parties in Croatia.

\section{Data Analyses}

To determine the magnitude and nature of the association between ideology and party preferences and electoral choice we used several statistical procedures. First, we computed zero-order correlations which provided initial insight into the interrelations between variables.

Secondly, we carried out hierarchical regression analysis to establish the relative importance of socioeconomic status and ideology as predictors of voting preferences and electoral behavior, conceived both as a single left-right dimension and as empirically derived basic ideological factors from underlying social attitudes.

Prior to performing the analysis, the criterion variables were first transformed from categorical (party choice) to ordinal, i.e. left-right dimension based on earlier research of Croatian citizen perception (Milas \& Rimac, 1994; Milas, 1992). Thus, we performed separate analyses on the data from the surveys conducted 2003, 2014 and 2016 with education, household income and ideology as predictors and ideological placement of the chosen party as a criterion. In the first model of the hie- 
rarchical regression analysis, only income and education were included, and then in the next step indicators of one's ideological position were added as predictors.

In addition, a discriminatory analysis was utilized using party choice as a categorical variable. To enable the centroid estimation, only parties selected by at least 30 participants were included in the analysis. We again used indicators of ideological position as explanatory variables to determine the extent to which groups of voters of the most popular Croatian political parties can be discriminated.

Finally, we explored the meaning of the left-right ideological dimensions in terms of general social attitude dimensions. The overlap between differently operationalized ideological dimensions was measured at three time points using regression analysis.

\section{RESULTS}

Table 1 provides statistical descriptors of ideological indicators in all three survey samples. Because of the difference in the scale range of some corresponding measures, as well as the varying number of SAS_G scale items as a result of limited space in the questionnaires, the means from different surveys are not comparable but merely provide orientational values.

Table 2 shows the correlations between the measures used in the survey in 2003 and in surveys 2014/2016 combined. We merged the samples from two studies close in time as the correlations between corresponding variables were mostly similar. The number of statistically significant differences between corresponding correlati-

Table 1. Statistical Descriptors of ideological indicators observed at three time points

\begin{tabular}{|c|c|c|c|c|c|c|}
\hline & \multicolumn{2}{|c|}{$2003(\mathrm{n}=1248)^{\mathrm{a}}$} & \multicolumn{2}{|c|}{$2014(\mathrm{n}=1000)$} & \multicolumn{2}{|c|}{$2016(n=750)$} \\
\hline & M & sd & M & sd & M & sd \\
\hline Left-Right self-placement & 5.39 & 2.35 & 5.43 & 2.38 & 5.57 & 2.36 \\
\hline Religiosity (SAS_G) & 2.65 & 0.56 & 3.79 & 1.13 & 3.55 & 1.14 \\
\hline Sexual Freedom (SAS_G) & 2.13 & 0.69 & 2.04 & 1.06 & 2.96 & 1.05 \\
\hline Cosmopolitism (SAS_G) & 2.81 & 0.40 & 3.65 & 0.95 & 3.59 & 0.82 \\
\hline Modern Technology (SAS_G) & 2.87 & 0.32 & 3.82 & 0.99 & 4.13 & 0.80 \\
\hline Social Justice (SAS_G) & 2.79 & 0.35 & 4.16 & 0.95 & 4.27 & 0.78 \\
\hline
\end{tabular}

Notes: SAS_G= General social attitude scale

$* \mathrm{p}<.05, * \bar{*} \mathrm{p}<.01$

aThe 2003 survey used a Left-right self-placement scale that ranged from 1 to 10, and in 2014 and 2016 scale ranging from $0-10$, therefore they were not comparable. Likewise, the means for SAS_G are also not comparable because in 2003 a three-point scale was applied with 15 items, whereas in 2014 and 2016 a five-point scale was used with 10 and 25 items respectively. 


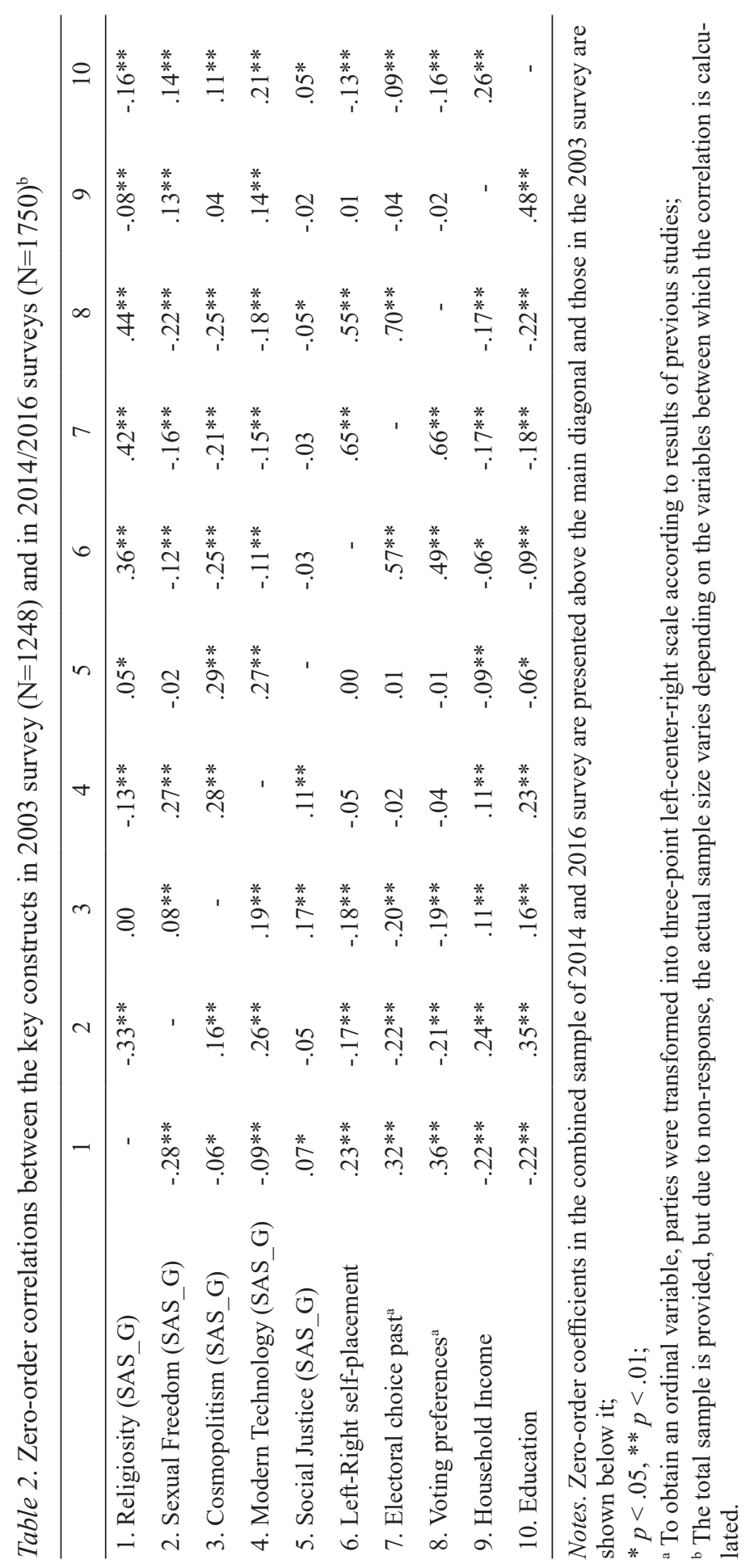




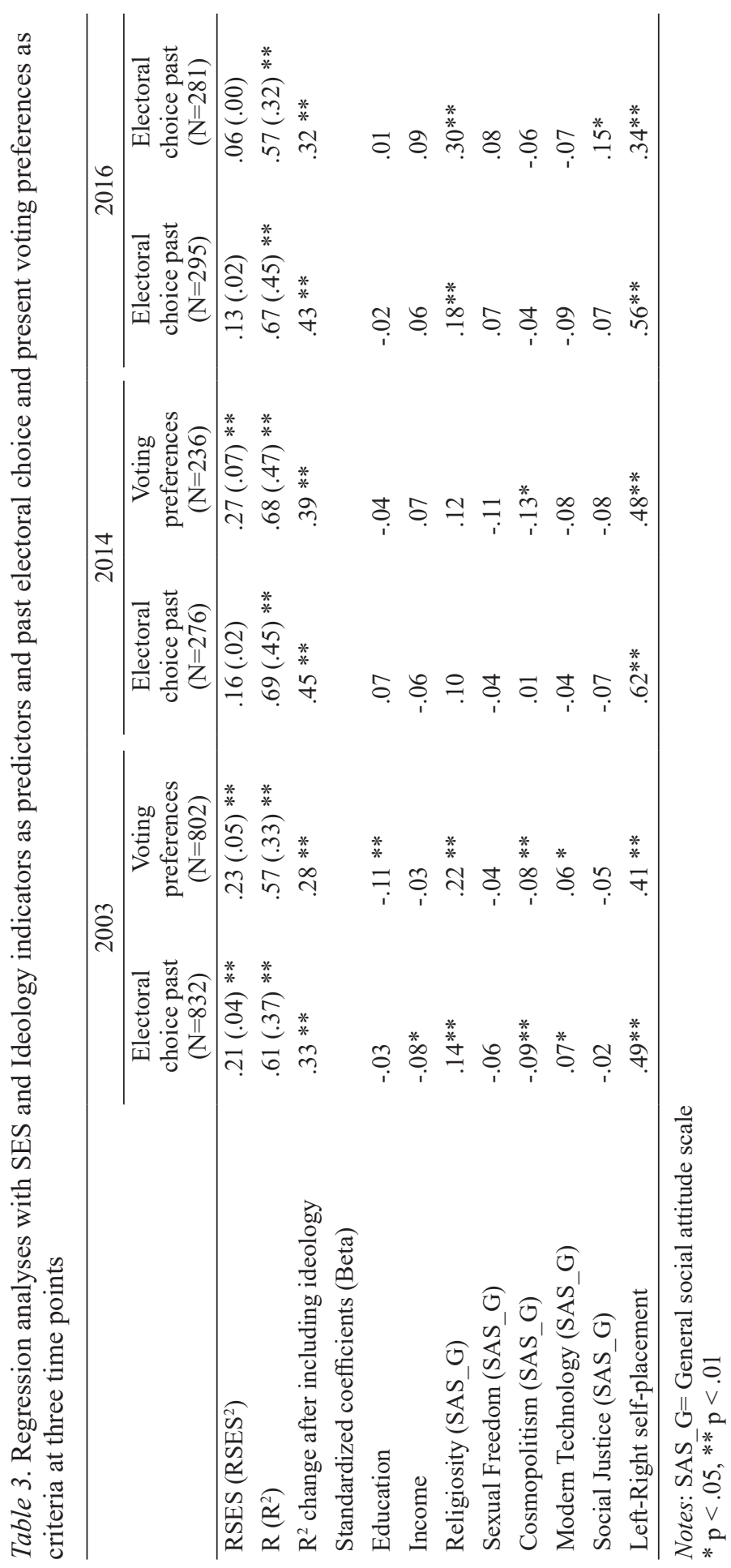


ons was around $5 \%$, just what was to be expected due to sampling error. The matrix of correlations between the ideology indicators and the party preferences is generally consistent across two time points. However, already at first glance, ideology in the later period seems to explain a slightly larger proportion of the variance of electoral choice and party preference.

And it is precisely regression analysis that can provide more accurate data on the total explained variance of party preference and the contribution of individual predictors. Table 3 presents the basic statistical descriptors of regression analyses conducted at different time points with ideological indicators as predictors and political preferences as criteria.

The first finding to be emphasized is a very small and sometimes absent association between the indicators of socio-economic status and political preferences, unlike earlier research conducted just after the introduction of democracy in Croatia (Rimac, 1992). It is true that the SES is represented by only two variables, education and household income and it is likely that the inclusion of some additional indicators, such as occupation or material possessions, would increase the explained variance to some extent. But this change, if it were to occur at all, would certainly not be dramatic, so we can reasonably conclude that the SES played a very limited role as a predictor of electoral decision or party preference in the observed period.

Unlike the SES, which plays a minor role in prediction, ideological factors at each measurement point explain a moderate proportion of variance of party preference and electoral choice, at some points even around 50 percent. It should be noted, though, that party preferences are reduced to ideological left-right metrics and thus the ideological role may be somewhat overestimated, especially since the transformed variable is similar in content to its major predictor, i.e. left-right selfplacement.

As noted earlier, one of the aims of the current study was to test the usefulness of the magnitude of the association between ideology and electoral choice as an indicator of the democratic maturation of a transitional society. Comparing the variance explained solely by ideological indicators, we can see that it is generally higher in 2014 and 2016 compared to 2003 (it is statistically significant in three out of four comparisons). There is no statistically significant difference between 2014 and 2016, which is expected given the short time between them.

As we mentioned earlier, left-right self-placement is by far the strongest ideological predictor, perhaps partly because of the previously mentioned content match with the criterion variable. Predictors in the domain of general social attitudes have significantly lower predictive power, partly due to overlap with left-right self-placement. Among them, religiosity is by far the most important, while others have minor predictive value in only a few of the analyses conducted.

The analysis of the interrelation between party preferences and ideological indicators was also carried out in another way, treating the criterion variable in its original form as nominal. Six discriminant analyses were conducted in which the 


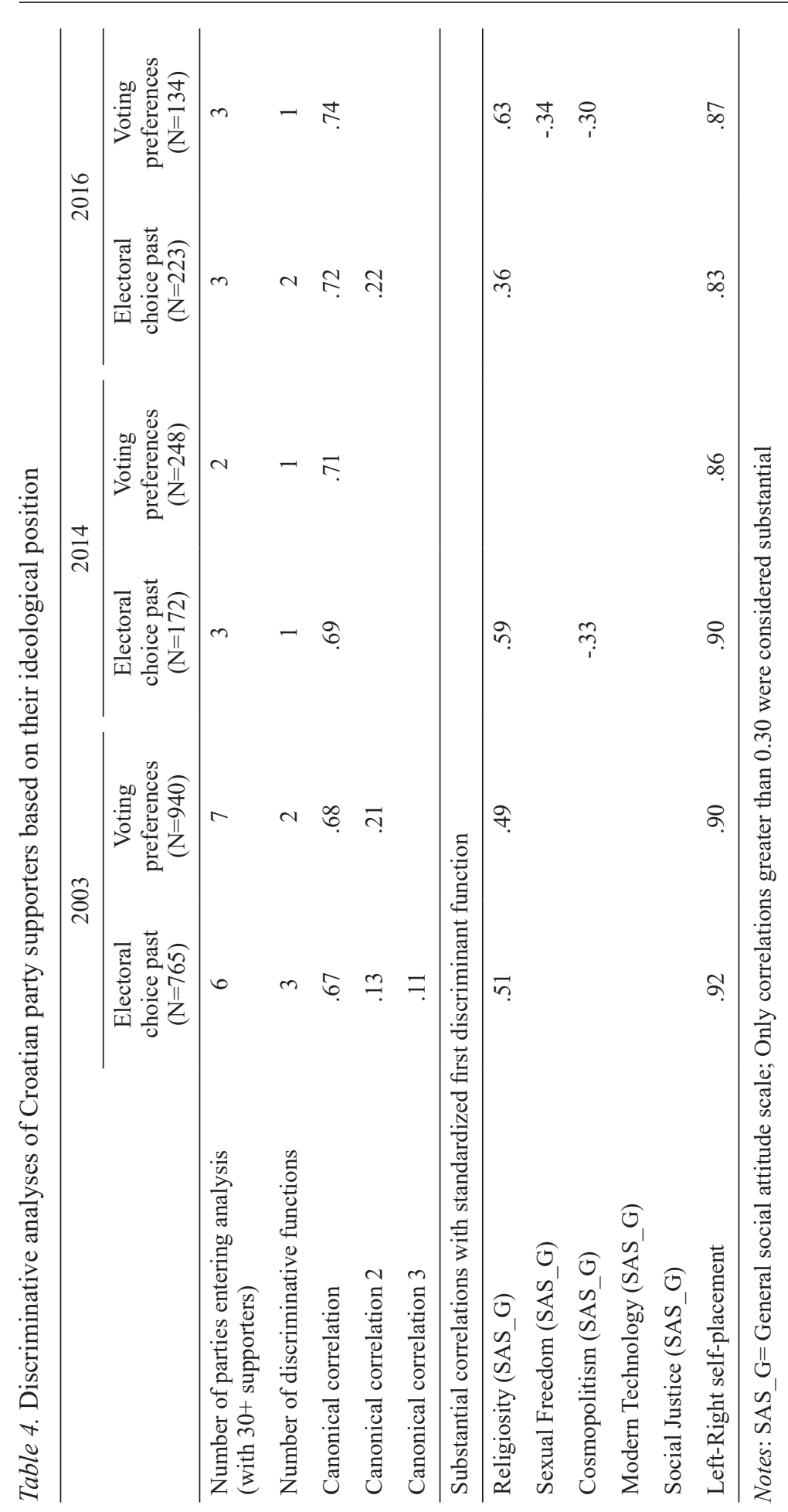


criterion variable belonged to a group that voted or intend to vote for a particular party and the discriminative variables were ideological indicators. To accurately estimate the centroids of likely voters of a party, we had to limit ourselves to those with the support of no less than 30 respondents. Along with non-response, this substantially reduced the number of respondents and parties included in the analyses.

Table 4 shows the results of the discriminatory analyzes conducted, together with the number of parties included, the number of significant discriminatory dimensions, and the standardized discrimination coefficients of the ideological variables.

What was revealed by the regression analysis was largely confirmed by the discriminant analysis. The strongest predictor of being a supporter of a particular party is the self-placement on the left-right dimension. Apart from it, only religiosity has a major role in discriminating supporters of different political parties. In virtually all analyses, a single discriminatory dimension dominates, which is either the only statistically significant one or the only dimension that substantially contributes in distinguishing supporters of different political parties.

As in the case of regression analysis, citizens have been shown to be reluctant to reveal their electoral choices in the past and current political preferences. As a result, the sample size dropped from relatively large to barely acceptable, which to some extent makes the results less compelling.

Two questions arise from the reduction of the initial sample. The first is the possibility that such a reduced sample is biased, and the second is that in most cases we narrowed the political space to two or fewer major parties. The reduced sample probably means that only the ardent supporters of the largest Croatian parties were

Table 5. Regression analyses with SAS_G subscales as predictors and Left-right self-placement as criterion at three time points

\begin{tabular}{lllc}
\hline & 2003 & 2014 & 2016 \\
\hline $\mathrm{R}$ & $0.30^{* *}$ & $0.46^{* *}$ & $0.44^{* *}$ \\
Standardized coefficients (Beta) & 0.09 & 0.21 & 0.19 \\
Religiosity (SAS_G) & & & \\
Sexual Freedom (SAS_G) & $0.19^{* *}$ & $0.37^{* *}$ & $0.38^{* *}$ \\
Cosmopolitism (SAS_G) & $-0.10^{* *}$ & 0.02 & 0.05 \\
Modern Technology (SAS_G) & $-0.16^{* *}$ & $-0.28^{* *}$ & $-0.25^{* *}$ \\
Social Justice (SAS_G) & 0.02 & 0.02 & -0.01 \\
\hline
\end{tabular}

Notes: SAS_G $=$ General social attitude scale

$* \mathrm{p}<.05,{ }^{*} \overline{\mathrm{p}} \mathrm{p}<.01$ 
retained in the analysis, which could have resulted in the loss of ideological subtleties characteristic of smaller and specific parties and their supporters on Croatia's political scene.

In previous analyses, we have observed that among Croatian citizens, the global ideological left-right dimension still dominates and is most closely linked to the electoral decision and party preferences. It remains to be seen what this dimension actually means in terms of general social attitudes and how its perceptions among citizens have changed since 2003.

Table 5 shows the results of regression analyses in which the predictors are general social attitudes and the criterion is self-placement on the left-right continuum. The first thing to notice is that in two recent studies, social attitudes explained the greater proportion of left-right self-placement variance, about twenty percent, compared to only nine percent in the first survey. The only two attitudinal dimensions that consistently have some predictive value in explaining the variance of left-right placement are religiosity and cosmopolitanism. In two later surveys, these two dimensions have greater predictive power than in the 2003 survey.

\section{DISCUSSION}

Although much research over the years has addressed the issue of the relationship between ideology and electoral choice and party preference (Elff, 2017), the complexity of the problem and many factors that influence this relation leave room for the exploration of additional aspects. In the current research, the focus is on examining this association as a possible indicator of the ideological and democratic maturation of the electorate in Croatia that accompanies democratic consolidation (Schedler, 1998). To study changes in the magnitude and nature of the correlation between ideological factors and electoral choice and voting intention, we used data from three surveys conducted over a 13-year period on probabilistic samples of the Croatian adult population.

A comparison with earlier research conducted in the 1990's in Croatia (Milas \& Rihtar 1997; Milas, 2000) has shown that ideology has since gained much importance as a predictor of voting preferences and electoral decisions. Although studies from the earlier period did not use the very same measures, it can still be concluded that no correlation between ideological indicators and electoral preferences explained more than 20 percent of the variance, whereas as early as 2003, approximately 30 percent was explained by regression analysis, and as much as $50 \%$ based on the canonical correlation of the first discriminatory dimensions. Between 2003 and 2014/2016, a further increase in the correlation between ideology and party preference was observed, to about forty percent measured by multiple correlation and more than 50 percent measured by discriminatory function. 
The results thus appear to confirm the phenomenon of strengthening the relationship between ideology and party preferences over time in Croatia. This process coincides with the consolidation of democracy and it is reasonable to assume that these two processes are somehow connected.

We have no evidence that one process affects the other, but there are clear indications that democratic consolidation and ideological maturation of the electorate, in which the correspondence between the advocated ideology and electoral preferences is strengthened, go hand in hand. Of course, this research could not rule out some alternative explanations. It is also possible that in some periods, parties struggling for center voters gave up strong ideological positions, which resulted in a smaller correlation between voter ideological position and party choice. At other times, the opposite process could have been in effect, the ideological distancing of parties, which led to an apparent increase in congruence between ideology and party preferences. Furthermore, longitudinal research has shown that party perceptions may change over time depending on prominent issues and voters' interest in those issues (Giebler, Meyer \& Wagner, 2019).

The same issue of the relationship between political competence and ideological consistency was approached in a slightly different way by Palfrey and Poole, who developed "an information index" which represented a measure of an individual's political knowledge, and came to an interesting conclusion, that the more information a voter has, the more likely that individual is ideologically extreme. Palfrey \& Poole (1987, p. 511) furthermore state: "Individuals with a high level of information tend to be more extreme than those with low levels and are much more likely to vote." Although their conclusions are very interesting and provocative, there are many differences between this study and Palfrey \& Poole (1987). First of all, the U.S.A. have a stable democratic political system far longer than Croatia does; second, the bipartisanism is probably more pronounced in the U.S.A. (although these tendencies are more present in Croatia in recent years); and finally, Palfrey \& Poole (1987) study dates from a pre-internet and pre-social network time. However, it would be interesting to conduct such a study in the modern Croatian political context.

As for the second hypothesis, the one regarding the diversification of ideological reasons for party support, the global left-right ideological dimension has been shown to remain dominant in the prediction of electoral choice and preferences. Studies show that no significant shift occurred within the observed period towards a larger role of attitudinal dimensions. However, more recently, attitudes have been shown to better explain the left-to-right dimension, which could also be an indicator of the ideological maturation of the electorate, as one often vague and ambiguous dimension takes on a clearer meaning.

Overall, the survey identified a shift in the expected direction, showing that the association between ideology and electoral behavior and preferences increases over the course of time. We presume that this change in the minds of voters is linked to 
the transitional processes and the consolidation of democracy so that the establishment and promotion of democratic institutions is accompanied by the acquisition of knowledge about the functioning of democracy and the multi-party system through both formal education, the media and informal sources. But clearly, it is possible that this is just a gradual shift of generations whereby the younger generation of adults who have come of age have a broader political culture than the older ones who grew up in socialism. We believe that the increasing importance of ideology as a predictor of electoral preferences reflects a widening knowledge of politics and ideology. Most of the population is likely to acquire knowledge through the media, while in young people this process also takes place through formal education. In conclusion, results of the study suggest that ideological literacy and the association of ideological preferences with electoral choice and preferences could be a useful complementary indicator of the consolidation of a transitional democracy.

\section{Limitations}

Like any other study, this one is subject to limitations that require results to be taken with caution. Despite the large and probabilistic samples, relatively few people have expressed political preferences which is why the correlation found among the investigated constructs is more susceptible to error than the entire sample would suggest. Also, the time period during which the studied constructs and their relationship were monitored, may be too short and the number of observation points are too few for fully grounded and firm conclusions. In addition, research on independent samples does not allow insight into changes taking place within people. Therefore, we cannot know whether the increase in the correlation between ideology and party preference reflects changes in people, generation shift, or both.

\section{REFERENCES}

Adorno, T., Frenkel-Brunswick, E., Levinson, D., \& Sanford, R. (1950). The authoritarian personality. New York: Harper.

Altemeyer, B. (1981). Right-wing authoritarianism. Winnipeg, MB: University of Manitoba Press.

Bauer, P. C., Barberá, P., Ackermann, K., \& Venetz, A. (2017). Is the Left-Right Scale a Valid Measure of Ideology?: Individual-Level Variation in Associations with "Left" and "Right" and Left-Right Self-Placement. Political Behavior, 39(3), 553-583. https://doi. org/10.1007/s11109-016-9368-2

Bowler, S. (2017). Party Identification. In: J. Fisher, E. Fieldhouse, M.N. Franklin, R. Gibson, M. Cantijoch \& C. Wlezien (Ed), The Routledge Handbook of Elections, Voting Behavior and Public Opinion (pp 146-157). London: Routledge.

Campbell, A., Converse, P.E., Miller, W.E. \& Stokes, D.E. (1960). The American Voter. Chicago: University of Chicago Press. 
Campbell, A., Gurin, G. \& Miller, W. E. (1954). The Voter Decides. Oxford: Row, Peterson, and Co.

Converse P.E. (2000). Assessing the Capacity of Mass Electorates. Annual Review of Political Science, 3(1), 331-353. https://doi.org/10.1146/annurev.polisci.3.1.331

Converse, P. E. (1964). The Nature of Belief Systems in Mass Publics, In D. E. Apter, (Ed.), Ideology and Discontent, (pp 206-261). New York: The Free Press.

Duckitt, J., \& Sibley, C. G. (2009). A Dual-Process Motivational Model of Ideology, Politics, and Prejudice. Psychological Inquiry, 20(2-3), 98-109. https://doi. org/10.1080/10478400903028540

Elff, M. (2017). Ideology and Electoral Choice. In: J. Fisher, E. Fieldhouse, M.N. Franklin, R. Gibson, M. Cantijoch \& C. Wlezien (Ed), The Routledge Handbook of Elections, Voting Behavior and Public Opinion (pp 136-145). London: Routledge.

Evans, G. \& De Graaf, N. D. (2013). Political Choice Matters: Explaining the Strength of Class and Religious Cleavages in Cross-National Perspective, Oxford: Oxford University Press.

Eysenck, H. J. (1944). General Social Attitudes. The Journal of Social Psychology, 19, 207-227.

Eysenck, H. J. (1954). The psychology of politics. New York: Praeger.

Ferguson, L.W. (1973). Primary social attitudes of the 1960s and those of the 1930s. Psychological Reports, 33, 655-664.

Giebler, H., Meyer, T. M., \& Wagner, M. (2019). The changing meaning of left and right: supply- and demand-side effects on the perception of party positions. Journal of Elections, Public Opinion and Parties. https://doi.org/10.1080/17457289.2019.1609001

Habermas J. (1989). The Theory of Communicative Action, Volume Two. Boston, MA: Beacon.

Jansen, G., Evans, G., \& Graaf, N. D. de. (2013). Class voting and Left-Right party positions: A comparative study of 15 Western democracies, 1960-2005. Social Science Research, 42(2), 376-400. https://doi.org/10.1016/j.ssresearch.2012.09.007

Jost, J. T. (2006). The end of the end of ideology. American Psychologist, 61(7), 651-670. https://doi.org/10.1037/0003-066X.61.7.651

Jost, J. T., Federico, C. M., \& Napier, J. L. (2009). Political ideology: its structure, functions, and elective affinities. Annual Review of Psychology, 60, 307-337. https://doi. org/10.1146/annurev.psych.60.110707.163600

Jost, J. T., Glaser, J., Kruglanski, A. W., \& Sulloway, F. J. (2003). Political conservatism as motivated social cognition. Psychological Bulletin, 129(3), 339-375. https://doi. org/10.1037/0033-2909.129.3.339

Kaliterna Lipovčan, L. (2016). Pilar's Barometer of Croatian Society 2016. Institute Pilar: Zagreb.

Kerlinger, F.N. (1972). The structure and content of social attitude referents: A preliminary study. Educational and Psychological Measurement, 32, 613-630.

Klingemann, H. D. (1972). Testing the Left-Right Continuum on a Sample of German Voters. Comparative Political Studies, 5(1), 93-106.

https://doi.org/10.1177/001041407200500105

Knapp, A. \& Wright, V. (2006). The government and politics of France. New York: Routledge. 
Knight, K. (2006). Transformations of the concept of ideology in the twentieth century. American Political Science Review, 100(4), 619-626. https://doi.org/10.1017/ S0003055406062502

Lamza Posavec, V., Ferić, I. \& Rihtar, S. (2003). Javno mnijenje Hrvatske: Izbori za Hrvatski sabor 2003. [Public opinion of Croatia: Elections for Croatian Parliament 2003]. Zagreb: Institut Pilar.

Laponce, J. A. (1970). Note On the Use of the Left-Right Dimension. Comparative Political Studies, 2(4), 481-502. https://doi.org/10.1177/001041407000200405

Marx K. \& Engels, F. (1974). The German Ideology. London: Lawrence \& Wishart. (Original work published 1846).

Milas, G. \& Rihtar, S. (1997). Ideološke odrednice·stranačke naklonosti i namjere glasovanja [Ideological determinants of party preference and voting intentions]. Društvena Istraživanja, 6, 663-676.

Milas, G. \& Žakić Milas, D. (2003). Ličnost i društveni stavovi: Povezanost temeljnih dimenzija [Personality and social attitudes: Relationship between basic dimensions]. Društvena Istraživanja, 12, 519-539.

Milas, G. (1992). Mišljenje javnosti o hrvatskim političarima i političkim strankama kao pokazatelj dimenzionalnosti i prirode hrvatskog političkog prostora. [Public opinion on Croatian politicians and political parties as indicators of dimensionality and the nature of the Croatian political scene]. Društvena Istraživanja, 1, 245-264.

Milas, G. (2000). Razlozi nedosljednosti : tko i zašto mijenja glasačku odluku? [Reasons of inconsistency: Who changes their voting decision and why?]. Društvena Istraživanja, 9, 473-496.

Milas, G. (2004). Ličnost i društveni stavovi [Personality and social attitudes]. Jastrebarsko: Naklada Slap.

Milas, G., \& Burušić, J. (2004). Ideološki i sociodemografski profili glasača hrvatskih političkih stranaka: ususret stabilnom političkom grupiranju? [Ideological and Sociodemographic Profiles of Voters of Croatian Political Parties: Towards Stable Political Grouping?]. Drustvena Istraživanja, 13, 347-362.

Milas, G., \& Rihtar, S. (1998). Struktura društvenih stavova u Hrvatskoj [The structure of social attitudes in Croatia]. Društvena Istraživanja, 7, 885-905.

Milas, G., \& Rimac, I. (1994). Model hrvatskoga političkog prostora, dimenzioniran stavovima glasača, [A Model of Croatian Political Scene]. Revija za sociologiju, 25, 9-22.

Milas, G., Mlačić, B., \& Mikloušić, I. (2013). Construct Validation of a General Social Attitudes Scale (SAS_G). Journal of Individual Differences, 34(4), 203-213. https://doi. org/10.1027/1614-0001/a000115

Miletić, G. M. (2014). Pilar's Barometer of Croatian Society 2014. Institute Pilar: Zagreb.

Mishler, W., \& Rose, R. (2001). Political Support for Incomplete Democracies: Realist vs . Idealist. Theories and Measures, 22(4), 303-320.

Palfrey, T.R. \& Poole, K.T. (1987). The Relationship between Information, Ideology, and Voting Behavior. American Journal of Political Science, 31(3), 511-530.

Rimac, I. (1992). Socijalni status i politička odluka - izbori 1992. [Social status and political decision: The 1992 elections]. Društvena Istraživanja, 1, 265-274. 
Saucier, G. (2000). Isms and the structure of social attitudes. Journal of Personality and Social Psychology, 78(2), 366-385. https://doi.org/10.1037//0022-3514.78.2.366

Saucier, G. (2013). Isms dimensions: Toward a more comprehensive and integrative model of belief-system components. Journal of Personality and Social Psychology, 104(5), 921-939. https://doi.org/10.1037/a0031968

Schedler, A. (1998). What is democratic consolidation? Journal of Democracy, 9(2). https:// doi.org/10.1353/jod.1998.0030

Sidanius, J., \& Pratto, F. (1999). Social dominance: An intergroup theory of social hierarchy and oppression. Cambridge, UK: Cambridge University Press.

Wilson, G. D., \& Patterson, J. R. (1968). A new measure of conservatism. British Journal of Social and Clinical Psychology, 7, 264-269.

Wilson, G.D. (1973). The psychology of conservatism. London: Academic Press.

\title{
POVEZANOST IZMEĐU IDEOLOGIJE I BIRAČKIH PREFERENCIJA U VREMENSKOJ PERSPEKTIVI: POKAZATELJ IDEOLOŠKOG SAZRIJEVANJA MLADE DEMOKRACIJE?
}

\begin{abstract}
Sažetak
Brojna su se istraživanja bavila odnosom između ideologije, stranačkih preferencija i biračke odluke. Međutim, zbog složenosti odnosa, razlike u poimanju ideologije i raznolikosti političkih sustava, to pitanje još uvijek nije dokraja istraženo. Postojeće istraživanje pristupa problemu prateći dinamiku promjene u povezanosti između ideološke pozicije i stranačkih preferencija tijekom vremena u Hrvatskoj. Podaci su prikupljeni u tri nacionalna anketna istraživanja provedena 2003. godine $(\mathrm{N}=1248)$, 2014. $(\mathrm{N}=1000)$ i 2016. ( $\mathrm{N}=750)$ na reprezentativnim uzorcima hrvatske punoljetne populacije. Ideološka pozicija pojedinca je mjerena dvojako, korištenjem Ljestvice općih društvenih stavova (SAS_G) i samopozicioniranja na dimenziji lijevo-desno. Preferencije prema političkim strankama mjerene su putem iskaza o biračkom odabiru na prethodnim izborima i iskazanim biračkim namjerama na predstojećim izborima. Rezultati upućuju na postojani porast povezanosti između ideoloških faktora i političkih preferencija tijekom godina. U radu argumentiramo kako povećana korespondencija ideologije i političkih preferencija među biračima može poslužiti kao dodatni pokazatelj demokratske konsolidacije u tranzicijskim i post-tranzicijskim zemljama poput Hrvatske. Ali, za razliku od demokratske konsolidacije koja se odvija izvana i uključuje izgradnju demokratskih institucija, ova promjena odvija se u umovima građana koji proširuju i produbljuju vlastitu političku kulturu, znanje o ideologiji i postaju svjesniji implikacija vlastitih biračkih odluka.
\end{abstract}

Ključne riječi: ideologija, društveni stavovi, politički stavovi, političke preferencije, izborna odluka, Hrvatska

Primljeno: 10. 12. 2019. 
Milas, Mlačić, The Relationship between Ideology and Voting Preferences in the Time Perspective, Suvremena psihologija 22 (2019), 2, 161-179 